\title{
Model Pengembangan Kreativitas dan Inovasi dalam Membentuk Entrepreneur di Era Ekonomi Digital
}

\author{
Hamdan \\ Fakultas Ekonomi, Universitas Serang Raya, Serang \\ hamdanunsera@gmail.com
}

\begin{abstract}
This study aims to develop a model of creativity and innovation in building the entrepreneurial spirit. The population are 145 young people from the study group in Anyer District, Serang Regency. The location selection is based on the fact that young people in that area are more interested in working on the Cilegon industrial area than become entrepreneurs, while business opportunities in the digital economy era are wide open to the younger generation. The research data is collected by giving tests, questionnaires, guidelines, observations, interviews and documentation studies. The data is analyzed using descriptive analysis, percentage, with non-parameter statistics with Microsoft Excel, and SPSS 19. The results of this study show that: 1) model planning is ready to be carried out based on theory and empirical research results in field of entrepreneurship courses in structured concept;. 2) the process of applying this model is carried out in community learning groups through three stages: introductory material, model development, and model testing; 3) the model that encourages the development of creativity and entrepreneurial innovation towards community learning groups is a training model oriented to build the entrepreneurial spirit in the digital economic era; 4) This training model enables the creation of entrepreneurial institutions in the digital economic era that require more creativity and innovation.
\end{abstract}
Keywords : Creative, Digital Economy, Entrepreneurship, Innovation, Training Model

\section{PENDAHULUAN}

Sebagaimana data dalam Badan Pusat Statistik (BPS) pada Agustus 2017, menunjukkan bahwa angka pengangguran di Indonesia masih tinggi yaitu sebanyak 7,04 juta. Salah satu faktor yang menyebabkan tingginya angka pengangguran di Indonesia adalah terlampau banyaknya tenaga kerja yang diarahkan ke pekerjaan sektor formal, sehingga ketika lapangan pekerjaan di sektor formal tidak tumbuh dan berkembang, individu tidak berusaha untuk menciptakan pekerjaan sendiri disektor swasta (Andika \& Majid 2012). Hal inilah yang menyebabkan masih tingginya jumlah pengangguran yang mengakibatkan lambannya atau rendahnya pertumbuhan ekonomi di Indonesia. Kondisi tersebut didukung pula oleh kenyataan bahwa sebagian besar lulusan perguruan tinggi masih sebagai pencari kerja (job seeker) dari pada pencipta lapangan kerja (job creator). Hal ini disebabkan karena sistem akademik dan kurikulum yang berbasis pada pembelajaran yang diterapkan di perguruan tinggi saat ini bukan menyiapkan lulusan yang siap menciptakan lapangan pekerjaan. Dalam era digital saat ini merupakan saat yang paling 
menguntungkan bagi banyak pihak terutama masyarakat Indonesia, seiring dengan bertambahnya pengguna internet di seluruh dunia terutama di Indonesia mencapai 51\% dari total penduduk Indonesia sebesar 256 juta jiwa. Data tersebut sebagai peluang yang menggiurkan untuk membuka pintu bisnis on line, karena mayoritas pengguna internet juga aktif dalam media sosial, perkembangan internet yang pesat juga dipengaruhi oleh kesiapan infrastruktur teknologi informasi yang menyediakan akses jasa internet yang menyeluruh dan semakin cepat.

Salah satu cara untuk menumbuhkembangkan jiwa kewirausahaan pada pemuda diperlukan usaha nyata yang terprogram dalam kurikulum pada pelatihan kelompok belajar masyarakat kewirausahaan. Namun pembekalan dan penanaman jiwa entrepreneur pada pemuda yang umumnya lulusan SMA atau Perguruan Tinggi ternyata belum dapat memotivasi diri untuk melakukan kegiatan kewirausahaan. Selain itu, pengalaman yang diperoleh dari bangku sekolah atau kuliah belum dapat ditindak lanjuti setelah lulus, sehingga belum mampu melahirkan wirausaha baru yang menguasai Sistem Informasi (IT) yang dapat menciptakan lapangan kerja sekaligus dapat menyerap tenaga kerja.

Melihat permasalahan di atas, dipandang perlu untuk menerapkan model dalam pengembangan kreativitas dan inovasi kewirausahaan di era ekonomi digital, sehingga dapat dijadikan rujukan mengenai bestpractices model pelatihan kewirausahaan dalam mengembangkan kreativitas dan inovasi bagi para pemuda dalam berwirausaha di era ekonomi digital. Mengingat kompleknya permasalahan yang ada dalam sistem dan proses pelatihan ini, peneliti mencoba merumuskan model pelatihan kewirausahaan dalam mengembangkan kreativitas dan inovasi dalam berwirausaha di era ekonomi digital pada para pemuda sebagaimana tujuan penelitian ini yaitu untuk mengetahui model dalam mengembangkan kreatifitas dan inovasi dalam kewirausahaan untuk menjalankan berwirausaha pada era ekonomi digital bagi para pemuda yang lebih kreatif dan inovasi

Untuk memudahkan membentuk model tersebut, ditentukan beberapa rumusan masalah sebagai berikut: 1) Bagaimana perencanaan model pelatihan kewirausahaan dalam mengembangkan kreativitas dan inovasi?; 2) Media pembelajaran kewirausahaan dalam bentuk apa yang sesuai dalam mengembangkan kreativitas dan inovasi?; 3) Bagaimana metode pelatihan kewirausahaan yang dapat mengembangkan kreativitas dan inovasi di era ekonomi digital?; 4) Bagaimana evaluasi yang diterapkan untuk mengetahui efektivitas model pelatihan kewirausahaan dalam mengembangkan kreativitas dan inovasi dalam berwirausaha di era ekonomi digital bagi para pemuda?

\section{Entrepreneurship Education}

Kuratko (2004) menjelaskan bahwa, entrepreneurship adalah proses dinamis atas visi, perubahan, dan kreatifitas. Entrepreneurship merujuk pada sebuah penerapan kekuatan dan dorongan dari dalam menuju kreativitas dan penerapan ide baru dan jalan keluar yang kreatif. Alberti, Sciascia, dan Poli (2004) dalam mengkaji entrepreneurship education menjelaskan bahwa keberhasilan seseorang dalam berwirausaha dipengaruhi oleh iklim usaha yang diciptakan oleh Negara, dukungan dunia pendidikan, dunia usaha itu sendiri yang juga harus bergairah. Pendidikan kewirausahaan menurut hasil penelitian yang dilakukan Welsch (1993) disimpulkan bahwa ada 2 (dua) faktor yang dapat diterapkan di kelas untuk meningkatkan kemampuan kewirausahaan, yaitu faktor dari dalam sekolah dan dari luar sekolah. Faktor dari dalam sekolah berupa pelatihan menumbuhkan jiwa kewirausahaan, dan faktor dari luar berupa keikusertaan dunia industri dalam melatih kemampuan kewirausahaan siswa, baik siswa langsung ke perusahaan, atau perusahaan mendatangi sekolah untuk melakukan pelatihan.

Winslow, Solomon, dan Tarabishy (1997) menyimpulkan bahwa pendidikan 
kewirausahaan dan praktik mendirikan usaha kecil yang dibimbing oleh guru, ternyata tidak serta merta mampu meningkatkan kemampuan kewirausahaan siswa, akan tetapi pembelajaran kewirausahaan dengan menggunakan self directed learning, mampu meningkatkan kemampuan kewirausahaan siswa. Hal ini sesuai dengan hasil penelitian yang dilakukan oleh Power dan Dougall (2005) yang menyimpulkan bahwa perguruan tinggi dalam perspektif kewirausahaan dapat dijadikan sebagai penyuplai teknologi inovasi yang masih baru dan belum ditemukan atau digunakan oleh orang lain bagi perusahaan yang sudah go public.

$$
\text { Berkaitan dengan budaya }
$$

berwirausaha, Naughton dan Cornwall (2009) pernah melakukan penelitian tentang culture as the basis of the good entrepreneur, menyimpulkan bahwa budaya sebagai dasar terbentuknya jiwa kewirausahaan yang baik. Budaya yang baik akan menghasilkan karakter yang baik, mendorong seseorang untuk melakukan inovasi, mendorong semangat moral dan spiritual untuk berusaha.

Yohnson (2003) yang meneliti tentang peranan universitas dalam memotivasi sarjana menjadi young entrepreneur menyimpulkan bahwa peranan universitas dalam memotivasi sarjana menjadi wirausaha muda sangat penting, sehingga akan mengurangi jumlah pengangguran, dan mampu menambah jumlah lapangan pekerjaan. Upaya yang bisa dilakukan seperti memberikan pendidikan kewirausahaan dan memberikan wadah bagi mahasiswa dalam menerapkan ilmunya dengan mendirikan bisnis kecil dilokasi kampus.

Sapienza dan Grimm; Watson, et al dalam Balboni (2014) menjelaskan faktor yang mempengaruhi pertumbuhan atau munculnya usaha baru yaitu faktor pendidikan tinggi. Pendidikan menjadi tolak ukur bahwa semakin tinggi tingkat pendidikan seseorang maka keterampilan wirausaha juga meningkat. Faktor kedua pengalaman berwirausaha yang berarti seseorang dengan pengalaman berwirausaha sebelumnya telah terbiasa mengahadapi ataupun mampu menghindari kesalahan. (Cooper, et al. dalam Balboni, 2014). Faktor selanjutnya yaitu jaringan yang luas yang berarti pendiri usaha memiliki jaringan luas yang akan menguntungkan usahanya alam aspek modal dan pelanggan. Orientasi berwirausaha juga merupakan faktor pendorong yang menjelaskan berbagai hal mengenai inovasi, berani mengambil resiko untuk mencoba hal baru dan mampu melihat peluang baru. Faktor terakhir menurut Baum et al dalam Balboni (2014) yaitu motivasi dan tujuan yang menjelaskan mengenai visi dari pendiri usaha dimasa depan yang lebih menantang. Dengan demikian, niat berkorelasi dengan perilaku, semakin kuat niat maka akan mempengaruhi perilaku tersebut (Ajzen dalam Hall \& Devaney 2009). Oleh karena itu, niat berwirausaha berfungsi sebagai mediator terhadap tindakan.

\section{Digital Business}

Dalam memulai sebuah start-up bisnis harus dimulai dari niat calon pelaku usahanya, munculnya niat yang akan berimbas pada perilaku dari calon pelaku usaha internet jelas berbeda dengan niat berwirausaha oleh pelaku usaha fisik sebenarnya. Perbedaan yang jelas yaitu ada pada kondisi usaha yang berupa modal, tempat dan produk. Aspek modal ada perbedaan pada jenis usaha fisik dengan usaha online yang banyak perhitungan mengenai kebutuhan yang cukup besar, karena memperhitungkan berbagai hal untuk perizinan usaha dan bahan baku/produk utama yang diperdagangkan. Jika usaha online tidak terikat aturan yang ketat mengenai modal, karena mayoritas pelaku/calon pelaku usaha digital tidak mensyaratkan banyakanya modal seperti usaha konvensional. Pendidikan merupakan salah satu faktor yang menjadi tolak ukur oleh pelaku usaha, banyaknya jumlah pengguna teknologi/gadget berada pada usia 20 tahun keatas, yaitu pada usia produktif. Kesempatan bagi usia produktif untuk 
mampu memanfaatkan banyak peluang dalam usaha.

Pada hasil survey tahun 2016 oleh APJII diperoleh data bahwa $62 \%$ atau 80 juta lebih pengguna internet digunakan untuk online shop, data tersebut merupakan informasi bahwa kesempatan bagi pelaku usaha digital untuk segera memulai usaha. Banyaknya peluang dalam bisnis digital belum maksimal disebabkan berbagai alasan, kurangnya pemahaman pelaku usaha mengenai teknologi informasi, kreativitas dan inovasi usaha, serta pengelolaan manajemen dalam bisnis digital dan strategi.

Semua aspek tersebut masih banyak dimiliki oleh para pemuda atau remaja yang sebetulnya sudah memahami teknologi informasi namun belum mampu melakukan tindakan nyata karena niat dan minat dalam berwirausaha itu belum muncul. Faktor pengetahuan dalam melihat peluang bisnis menjadi salah satu hal yang perlu diperhatikan pada pelaku usaha muda yang masih minim pengetahuan dan pengalaman wirausaha.

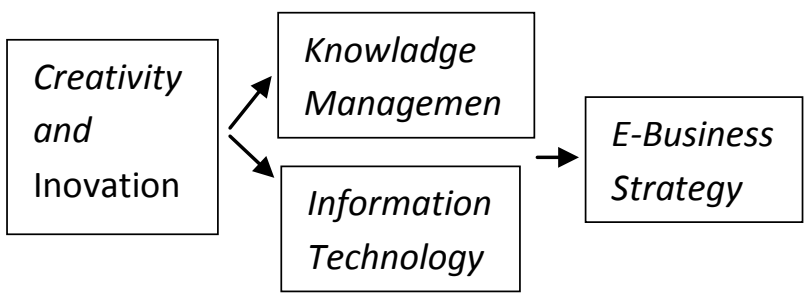

Gambar 1. Model of Knowledge Management (Sheung, 2014)

Van Horne et al., (2016) mengungkapkan kewirausahaan digambarkan sebagai suatu proses yang memanfaatkan kesempatan dan memperoleh pengakuan dari bisnis yang dibangunnya untuk memperoleh imbalan dari hasil kerja keras, melalui penjualan. Pemanfaatan kesempatan dalam bisnis digital yang masih sulit dilakukan oleh anak muda saat ini, karena mereka belum berfikir untuk menjadi pengusaha. Pada tahap proses membentuk wirausaha baru membutuhkan dukungan dari lingkungannya dan masing-masing memiliki metode belajar sendiri. Ada empat tahap dasar dari proses kewirausahaan tradisional seperti:

1. Kesempatan mengenal

Mengenal dalam hal ini berarti mampu mengenali kesempatan dan mengetahui peluang sekaligus mengenali dirinya sendiri apakah berminat untuk menjadi wirausaha.

2. Sumber daya

Pengelolaan sumber daya dalam diri wirausaha perlu untuk dikembangkan termasuk pengetahuan dalam pengelolaan teknologi informasi dan model yang digunakan untuk memulai sebuah start-up.

3. Peluncuran usaha

Memulai usaha start-up digital berbeda dengan memulai usaha konvensional. Start -up digital cenderung lebih fleksibel karena dapat dilakukan kapanpun dan dimanapun. Jadi tidak ada alasan sulit dalam peluncuran usaha awal.

4. Keberhasilan

Penuaian keberhasilan akan proses jalannya usaha bergantung dari proses awal hingga penuaian, dalam start-up digital yang masih tergolong usaha awal cenderung belum diketahui tingkat keberhasilannya.

Pengusaha digital memiliki beberapa tahap pengembangan usaha start-up antara lain sebagai berikut, (Asghari \& Gedeon, 2010):

1. Pree-seed

Tahap sebelum muncul benih dalam hal ini ide atau kreativitas bisnis digital, proses paling awal ketika sebelum menjadi wirausaha, calon pengusaha masih dalam tahap mencoba berbagai macam hal terkait bisnis digital dan masih mencari informasi dari berbagai sumber tentang kelengkapan bisnis.

2. Seed

Tahap benih ketika pengusaha mulai dengan mengembangkan ide dan kreativitasnya terkait pengetahuan dirinya dan kemampuannya untuk mencoba bisnis start-up. Tahap ini para pelaku bisnis masih cenderung ragu 
akan idenya, karena pasti berfikir idenya akan diterima atau ditolak pasar, pengambilan keputusan dalam tahap ini sangat berperan.

3. Start-up

Tahap ini mulai pembentukan dan pengimplementasian, karena produk dan jasa dari ide yang muncul pada tahap sebelumnya akan direalisasikan langsung melalui media online kepada konsumen.

\section{Expansion/Exit}

Tahap terakhir yaitu ekspansi atau dapat dikatakan produk dan jasa yang ditawarkan sudah diketahui oleh konsumen baru dan belum sampai ada tahap evaluasi atau komentar dari konsumen.

Esmaeeli, (2011) menambahkan bahwa kewirausahaan digital awal mulainya dimulai dalam mengembangkan atau digitalisasi usaha. Lingkup digitalisasi usaha berasal dari layanan digital yang tergolong cepat dan memuaskan sehingga dipilih untuk membuat hampir seluruh layanan menjadi digital. Potensi barang dan jasa lebih luas dengan jalur distribusi digital, potensi interaksi digital dengan pemangku kepentigan, dan potensi digital dari kegiatan internal terkait dengan oprasi perusahaan. Bisnis digital menjelaskan mengenai penciptaan nilai baru, yang melibatkan model bisnis baru berdasarkan barang dan layanan digital, distribusi digital, tempat kerja digital, dan pasar digital. Keberhasilan pengusaha dalam era digital dipengaruhi oleh beberapa sifat yang dijelaskan oleh Serarols dalam Van Horne, (2016) sebagai berikut:

1. Kemampuan dalam mempimpin

2. Kemampuan dalam mendelegasikan

3. Kemampuan dalam tim

4. Kemampuan dalam mengantisipasi risiko dan membuat keputusan

5. Profesional dalam keuangan

6. Percaya diri pada usaha atau bisnisnya

7. Usia yang jangan terlalu muda dan memiliki panutan atau pembimbing usaha
8. Memiliki keahlian dalam pemasaran maupun komunikasi

9. Mampu memilih kolega atau partner yang tepat

10. Gigih dalam mengembangkan kemampuan dan pengetahuan digital

11. Dinamis dan antusias dalam berbagai rintangan

12. Memiliki pengalaman dan kemampuan dalam industri, produk dan pasar

13. Sering mengikuti pelatihan bisnis digital Sifat-sifat tersebut menjelaskan perilaku pengusaha agar mampu meraih keberhasilan dalam bidangnya, tidak ada perbedaan mendasar mengenai sifat yang harus dimiliki oleh para pengusaha online dengan pengusaha konvensional.

\section{METODE}

Penelitian ini menggunakan pendekatan penelitian dan pengembangan (Research and Development) dari Gall dan Borg (2003: 569 dalam Sri Setiti, 2013) dan proses menguji efektivitas model terhadap penumbuhan kompetensi kewirausahaan dilakukan dengan pendekatan quasieksperimen. Kerangka yang digunakan oleh peneliti dengan merujuk pada Sukmadinata (2005: 189 dalam Sri Setiti, 2013), secara operasional prosedur penelitian ini dibagi dalam tiga tahapan utama, yaitu: 1) studi pendahuluan; 2) tahap pengembangan model; dan 3) tahap validasi/uji model. Penelitian dilakukan pada bulan Februari s.d Juli 2018 di Desa dan Kecamatan Anyer Kabupaten Serang sebagai kawasan wisata domestik lokal. Populasi penelitian ini adalah seluruh peserta didik dari kelompok belajar masyarakat tahun 2018 yang berjumlah 145 orang pemuda. Dari populasi sebanyak 145 ini, saat uji model lingkup terbatas diambil sampel dengan menggnakan teknik rundom sampling (teknik sampling acak sederhana) sebanyak 60 orang. Saat uji lingkup luas, sampel diambil dengan menggunakan sampel jenuh sebanyak 145 orang. Pengumpulan data menggunakan test, kuesioner, pedoman pengamatan, pedoman wawancara dan dokumentasi. Data yang terkumpul dianalisis dengan menggunakan 
analisis deskriptif, presentase dan statistik nonparametrik dengan program excel dan SPSS versi 19.

\section{HASIL DAN PEMBAHASAN \\ Perencanaan Pengembangan Model}

Perencanaan penyusunan dan pengembangan model dilakukan berdasarkan: 1) kajian teoritis dan 2) fakta empiris di lapangan baik secara konseptual maupun struktural. Pertama, kajian teoritis terhadap model inkubator bisnis menggnakan analisis SWOT. Hasil perhitungan SWOT menunjukan bahwa inkubator bisnis memiliki kekuatan yang lebih dominan dibandingkan kelemahannya dan peluang yang lebih besar dibandingkan ancamannya. Dengan memperhitungkan hasil analisis SWOT, posisi inkubator bisnis berada pada posisi keadaan bertumbuh, yaitu memanfaatkan seoptimal mungkin kekuatan memperoleh peluang-peluang yang tersedia diluar lingkungan inkubator bisnis.

Kedua, fakta empiris konseptual menunjukkan bahwa sarana pendukung pelaksanaan inkubator bisnis belum sepenuhnya tersedia, penumbuhan dan penetesan usaha melalui penyediaan fasilitas sarana dan prasarana belum dapat dilakukan dengan baik, struktur dan infrastruktur kurang memadai, administrasi belum dilakukan secara tertib dan rapi, akses jaringan usaha dan informasi serta akses jaringan modal atau pembiayaan di kalangan pemuda dirasakan masih kurang.

Adapun fakta empiris struktural menunjukkan bahwa model pengembangan kreatifitas dan inovasi kewirausahaan ini sebagai sebuah sistem yang terintegrasi yang memiliki nilai strategis dalam mengaplikasikan konsep link and match. Selain itu, model ini berfungsi sebagai wadah bagi pembinaan dan pengemabangan kewirausahaan para pemuda secara akademik yang tetap mengacu pada pengembangan sumberdaya manusia berdasarkan konsepkonsep akademik. Hasil penelitian ini diperkuat oleh penelitian Suwandi (2008) yang mengevaluasi model-model yang dikembangkan beberapa perguruan tinggi di
Indonesia, yang menyimpulkan bahwa seluruh perguruan tinggi sebelum menentukan model yang akan digunakan terlebih dahulu menyusun berbagai perencanaan model, sehingga dalam pelaksanaan pengembangan model dapat terlaksana dengan baik.

\section{Proses Penyusunan dan Pengembangan Model}

Proses penyusunan dan pengembangan model pelatihan kewirausahaan di kalangan para pemuda di kecamatan Anyer ini, dapat disimpulkan sebagai berikut: 1) Langkah pertama, melakukan studi pendahuluan untuk mengembangkan pra model pelatihan kewirausahaan yang meliputi studi kepustakaan/literature dan survey lapangan. Berdasarkan kedua hal tersebut dilakukan analisis SWOT dan analisis empiris baik secara konseptual maupun struktural. Langkah pertama ini menghasilkan pramodel pelatihan kewirausahaan; 2) Langkah kedua, melakukan pengembangan model, yang meliputi langkah validasi pramodel yang sudah ada oleh ahli dan pengujian model pelatihan kewirausahaan, baik skala terbatas maupun luas. Berdasarkan langkah-langkah tersebut terwujudlah model pelatihan kewirausahaan yang telah teruji secara teoritik dan empirik; 3) Langkah ketiga, melakukan uji model dengan membandingkan antara model yang diujicobakan dalam lingkup terbatas dan model yang diujicobakan dalam lingkup luas, sehingga tercipta model akhir pelatihan kewirausahaan di Kecamatan Anyer bagi para pemuda; 4) Langkah keempat, implementasi model sehingga menghasilkan output dan outcome.

Langkah-langkah pengembangan model di atas, pada dasarnya sesuai dengan langkah-langkah pengembangan inkubator bisnis yang telah di kembangkan oleh peneliti terdahulu seperti Buchori Alma (2008) dan Ardichvili et.al (2003). 


\section{Model Pelatihan Kewirausahaan yang Dikembangkan}

Model pelatihan kewirausahaan yang berorientasi pada pengembangan kreativitas dan inovasi dalam bentuk pelatihan dan praktik langsung pada UKM bisnis yang memproduksi berbagai jenis tas dan koper, budidaya rumput laut, dan koperasi. Bertujuan untuk menumbuh kembangkan Kompetensi Kewirausahaan yang dapat dijelaskan sebagai berikut: 1) Prinsip dasar model pelatihan kewirausahaan, sebagai suatu sistem pelatihan yang berkelanjutan, dalam arti peserta pelatihan tidak hanya lulus pelatihannya saja, akan tetapi yang bersangkutan disiapkan untuk menjadi wirausahawan yang handal dan mandiri di era ekonomi digital; 2) Karakteristik model meliputi: a) karakter model ini merupakan kesatuan program pelatihan bagi para pemuda; b) sebagai bentuk pelatihan dalam berwirausaha atau bisnis para pemuda yang dibangun atas dasar peluang dan potensi sumberdaya yang dimiliki pemuda; c) pelatihan kewirausahaan dilakukan sesuai dengan minat dan bakat para pemuda, dilaksanakan di lokasi UKM bisnis; d) model pelatihan kewirausahaan ini memerlukan kesediaan Pembina, pendamping dan kemitraan usaha dalam menjalankan bisnis baru; dan e) menekankan nilai kejujuran, keuletan, kecerdasan dalam memanfaatkan peluang, mampu melakukan analisis resiko dan berani mencoba menjadi bagian yang tidak terpisahkan dari pengembangan usaha bisnis. Komponen model meliputi: a) masukan input; b) proses pelatihan kewirausahaan yang terdiri dari teori dan praktik c) output; d) outcome; e) monitoring, evaluasi dan tindak lanjut. Untuk lebih jelasnya dapat dilihat pada model gambar 2 berikut ini:

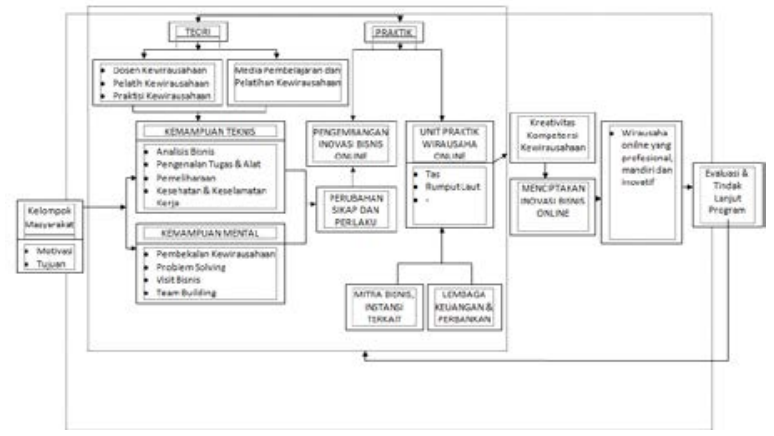

Gambar 2. Model Pengembangan Kreativitas dan Inovasi dalam Membentuk Enterpreneur di Era Ekonomi Digital

Prosedur operasional pelatihan model pelatihan kewirausahaan ini meliputi beberapa tahapan: 1) menjaring raw input yaitu para pemuda lulusan SMA atau Perguruan Tinggi; 2) Setelah mendapat raw input, mereka diberi pelatihan dan praktik dalam berwirausaha di UKM yang dilengkapi dengan sarana dan sumber belajar untuk melahirkan pengetahuan, keterampilan dan kompetensi kewirausahaan; 3) Setelah pelatihan teori keterampilan selesai, mereka dikelompokan dalam unit pengembangan dan inovasi sesuai dengan minat dan bakat pada UKM atau (industri berbagai jenis tas dan koper, budidaya rumput laut dan koperasi); 4) Selanjutnya setelah mengikuti proses pelatihan kewirausahaan ini menghasilkan output yang meningkatnya pengetahuan, sikap, keterampilan dan aktivitas peserta yang aktif dalam kegiatan pelatihan kewirausahaan yang meliputi; kompetensi kewirausahaan, kecakapan, keberhasilan, kerjasama dan dapat mempraktikan hasil pelatihan; 5) Pada tahap akhir dihasilkan outcome yaitu pemuda sebagai wirausahawan baru yang profesional, berwirausaha global, mandiri dan inovatif, mampu menciptakan peluang usaha sesuai hasil pelatihan; 6) untuk memantapkan proses pelatihan kewirausahaan dilakukan monitoring, evaluasi, dan tindak lanjut sebagai alat kontrol terhadap keberhasilan dalam proses pelatihan kewirausahaan dan upaya perbaikan dan inovasi bisnis sebagai turunan dari bisnis di era ekonomi digital. 
Hasil penelitian ini diperkuat oleh model yang dikembangkan oleh Lacho (2010), Kordnaeji, et.al (2011), Ardichvili at.al. (2003), Neck, Neck and Mayer (1998 dalam Lacho, 2010).

\section{Hasil Analisis Efektvitas Model Pengembangan Kreativitas dan Inovasi}

Berdasarkan hasil evaluasi dapat disimpulkan bahwa model pelatihan kewirausahaan yang berorientasi pada kreativitas dan inovasi pada kelompok eksperimen dapat dinyatakan efektif. Efektivitas pelatihan tersebut dapat dilihat dari: 1) Tercapainya tujuan sesuai dengan prioritas yang telah ditetapkan; 2) Memiliki kesesuaian dengan kebutuhan para pemuda yang berminat untuk menjadi entrepreneur di era ekonomi digital; 3) Berpengaruh positif terhadap peningkatan pengetahuan, sikap, perilaku dan keterampilan sangat mendukung terhadap peningkatan kompetensi kewirausahaan; 4) Dapat menggali, mengoptimalkan dan menyalurkan potensi, bakat dan minat berwirausaha; 5) Membantu, meningkatkan dan mempercepat proses pelatihan yang lebih kondusif. Hasil uji statistik diperoleh nilai t hitung kelompok eksperimen pengetahuan (9,54), sikap $(10,71)$ dan keterampilan $(12,88)$. Sedangkan kelompok kontrol (pembanding) nilai pengetahuan (7,76), sikap $(9,26)$ dan keterampilan $(10,58)$. Hasil ini membuktikan bahwa kelompok eksperimen nilainya cukup signifikan yaitu lebih besar dari nilai tabel $1 \%(2,62)$ dan $5 \%(1,76)$ serta lebih besar dari nilai kelompok kontrol baik pengetahuan, sikap maupun keterampilan. Hal ini menunjukkan bahwa model Pelatihan Kewirausahaan para pemuda yang berorientasi pada Kreativitas dan inovasi memberikan pengaruh yang lebih baik terhadap peningkatan hasil pelatihan dalam membentuk jiwa kewirausahaan bagi pemuda; 6) Mempunyai dampak yang baik bagi pemula, sehingga mereka memiliki minat untuk menyebarluaskan pengetahuan yang telah dimiliki kepada orang lain, memiliki motivasi, tanggung jawab, kreativitas, inovasi dan percaya diri yang lebih tinggi, salah satu peserta(dari kelompok eksperimen) siap diangkat sebagai tenaga penyuluh dalam proses pembuatan berbagai jenis tas atau koper dan pemeliharaan rumput laut, memiliki keinginan untuk membentuk organisasi profesi dan koperasi, mampu menumbuhkan jiwa wirausahawan serta kesadaran para pemuda akan kebersihan dan menjaga lingkungan dalam meningkatkan mutu produksi. Dampak positif dari pengembangan model ini bagi pemuda yaitu mampu meningkatkan kompetensi dalam kreativitas dan inovasi.

\section{Kesimpulan}

Berdasarkan hasil uji coba model, analisis data, dan pembahasan, simpulan hasil penelitian pengembangan model kreativitas dan inovasi ini dapat dirumuskan sebagai berikut :

Perencanaan penyusunan dan mengembangkan model pelatihan kewirausahaan dilakukan melalui: 1) kajian teoritik dan 2) fakta empiris dilapangan baik secara konseptual maupun structural. Kajian teoritis terhadap model pelatihan kewirausahaan ini menggunakan analisis SWOT. Hasil perhitungan SWOT menunjukkan bahwa model pelatihan kewirausahaan para pemuda yaitu memanfaatkan seoptimal mungkin kekuatan memperoleh peluang-peluang yang tersedia diluar lingkungan UKM. Proses penyusunan dan pengembangan model kreativitas dan inovasi, dapat disimpulkan sebagai berikut; Pertama, melakukan studi pendahuluan. Kedua, melakukan pengembangan model. Ketiga, melakukan uji model dengan membandingkan antara model yang diujicobakan skup terbatas dan model yang diujicobakan dengan skup luas, sehingga tercipta model akhir pelatihaan kewirausahaan pemuda di era ekonomi digital. Keempat, implementasi model sehingga menghasilkan output dan outcome. Model Pelatihan Kewirausahaan para pemuda yang berorientasi pada kreativitas dan inovasi ini, sebagai suatu sistem model pelatihan yang berkelanjutan, dalam arti 
peserta pelatihan yang berkelanjutan, dalam arti peserta pelatihan tidak hanya lulus pelatihan akan tetapi yang bersngkutan disiapkan untuk menjadi wira usahawan yang handal dan mandiri di era ekonomi digital dalam mengurangi pengangguran sebagaimana data di atas. Adapun komponen model meliputi beberapa hal: 1) masukan input; 2) proses pelatihan kewirausahaan dalam bentuk teori dan pelatihan; 3) output; 4) outcome; dan 5) monitoring, evaluasi dan tidak lanjut. Model Pelatihan Kewirausahaan para pemuda berorientasi pada kreativitas dan inovasi pada kelompok eksperimen dapat dikatakan efektif. Efektifitas pelatihan tersebut dapat dilihat dari: tercapainya tujuan sesuai dengan prioritas yang ditetapkan peserta dalam proses pelatihan kewirausahaan, memiliki kesesuaian dengan kebutuhan para pemuda, dan berpengaruh positif terhadap peningkatan pengetahuan, sikap, perilaku dan keterampilan, sangat mendukung terhadap peningkatan kompetensi kewirausahaan.

Berdasarkan kesimpulan yang diperoleh, dapat dirumuskan beberapa masukan yaitu : 1) Pemerintah hendaknya mempunyai kemauan politik (political will) bagi pelaksanaan pendidikan dan pembelajaran kewirausahaan di masyarakat dan perguruan tinggi, manakala menghendaki seluruh pemuda dapat menjadi wirausaha, dan tidak mengandalkan lapangan pekerjaan dari pemerintah maupun swasta; 2) Perlunya aksi bersama (collaborative action) dan dukungan dari pemerintah untuk research dan pengabdian kepada masyarakat (community service) dalam rangka mengembangkan program pendidikan kewirausahaan di perguruan tinggi, karena dirasakan begitu besar manfaatnya bagi Pemerintah dan masyarakat dalam mengurangi jumlah pengangguran di era ekonomi digital; dan 3) Model Pelatihan Kewirausahaan pada kelompok belajar masyarakat ini perlu diteliti lebih lanjut dengan pendekatan multi disiplin, multi model dan multi paradigma, dan temuan keilmuan yang dihasilkan dapat menyumbangkan hasanah keilmuan sehingga keberadaannya lebih kokoh.

\section{DAFTAR PUSTAKA}

Alberti, Fernando; Salvatore Sciacia, dan Alberto Poli, 2004, Enterpreneurship Education; Notes on and Ongoing Debate, $14^{\text {th }}$ Annual int. Ent. Conference, University of Napoli Federico II (Italy) 4-7 Juli 2004.

Alma, Buchari, 2003. Kewirausahaan. Bandung: Alfabeta.

Ardichvili, Alexander, Richard Cardozo, dan Sourav Ray, 2003: A Theory of Enterpreneurial Opportunity Identification and Development, Journal of Business Venturing, Vol. 18 pp. 105-123

Badan Pusat Statistik, 2010, Hasil Susenas, Jakarta: BPS

Brouwer, Maria T., 2002 Weber, Schumpeter, and Knight on Enterpreneurship and Economic Development, Journal of Evolutionary economics, Springer, Verlag, Vol. 12, 2002, pp 83-105

Dikti. Depdiknas, 2008, Materi TOT Soft Skill, Hotel Pangrangon Bogor tanggal 29-30 November 2006.

Disman, 2004, Efektivitas Pendidikan Ekonomi dalam Pembentukan nilainilai Perilaku Ekonomi (studi tentang faktor-faktor yang Mempengaruhi Efektifitas Pembelajaran Ekonomi dan Implikasinya terhadap Nilai-nilai Perilaku Ekonomi Berdasarkan Asas Kekeluargaan pada Siswa SMA Negeri di Kota Bandung), Disertasi, Bandung; PPs Universitas Pendidikan Indonesia.

Fauziah, Ali. R, Hendro Prabowo. Life Experience Pada Wirausaha Generasi Digital. Jurnal. Fakultas Psikologi Universitas Gunadarma

Pujiastuti, Eny Endah, dkk. (2008), Perpaduan anatar Teori dengan Praktek pada Model Inkubator Bisnis. Makalah

Kordnaeij, et.al, 2011origin of Journal of Global Enterpreneurship Research, 
Winter \& Spring, 011. Vol. 1 No. 1 pp 21-33

Kuratko, Donald F. 2004, Enterpreurship Eduvation in the $21^{\text {th }}$ Century: from Legitimazation to Leadership, A Coleman Foundation White Paper USASBE National Conference, Januari 16, 2004

Lacho, Kenneth, 2010, Enterpreneurship Education: Another Approach, Small Business Institute Journal, Vol. 5. April 2010 pp 67-82

Naughton, Michael dan Jeffry Cornwall, 2009, Culture as the Basic of The Good Enterpreneur, Journal of Religion and Business Ethics, Vol 1. Issue I, article 2. 2009

Powers, Joshua B dan Patricia P. McDougall, 2005, University Start-up Information and Technology Licensing with Firms that Go Public: a Resources-Based View of Academic Enterpreneurship, Journal of Business Venturing No 20 (2005), pp, 291-311Setiti, Sri, 2013, Pengembangan Sikap Kemandirian Melalui Pendidikan Kewirausahaan: Studi pada Mahasiswa Program Studi Pendidikan Ekonomi FKIP UNLAM Banjarmasin, Disertasi, Bandung: PPS, UPI Bandung

Stevenson, Howard H. 2000, Why entrepreneurship has won!,Coleman White Paper, USASBE Plenary Address, February 17, 2000

Suwandi, dkk. 2008, Pengembangan Model Inkubator Bisnis Perguruan Tinggi, Laporan Hasil Penelitian, Jakarta: Balibang Depdiknas

Welsch, P Harold, 1993, Enterpreneurship Education and Training Infrastructure; External Intervention in the Classroom, Paper Presented at the Conference Internationalizing Enterpreneurship Education and Training, Vienna Australia, July 5-7, 1993.

Winslow, Erik K; George T. Solomon; dan Ayman Tarabishy, 1997, Empirical Investigation into Enterpreneurship Education in the United State; Some Result of the 1979 National Survey of
Entrepreneurial Education, Paper Discusess National Survey of Enterpreneurship Education, 1997.

Yohnson, (2003). "Peranan Universitas dalam Memotivasi Sarjana Menjadi Young Enterpreneur "Jurnal manajemen \& Kewirausahaan. Vol 5 no 2 September (2003). Surabaya: Universitas Kristen Petra.

Sayydina Ali berkata: didiklah anak-anakmu sesuai zamannya, karena ia tidak hidup dizamanmu (kompasiana, 31 Oktober 2017). 